\title{
PENANAMAN NILAI-NILAI PENDIDIKAN ISLAM MELALUI MODEL MANAJEMEN MENTORING DI UKM KEROHANIAN IAIN CURUP
}

\author{
Lukman A ${ }^{1}$; Ade Surya²; Asri Karolina ${ }^{3}$; Ade Kurniawan ${ }^{4}$ \\ 1,2,3 Institut Agama Islam Negeri (IAIN) Curup, Bengkulu, Indonesia \\ ${ }^{4}$ Sekolah Tinggi Agama Islam Negeri (STAIN) Teungku Dirundeng Meulaboh \\ Email kontributor: lukman.asha@iaincurup.ac.id
}

\begin{abstract}
Abstrak
Penelitian ini bertujuan penemukan jawaban tentang penanaman nilai-nilai Pendidikan Islam melalui model mentoring di UKM kerohanian, penelitian ini menggunakan pendekatan kualitatif dengan informan kunci adalah mahasiswa yang tergabung dalam dalam UKM kerohanian IAIN Curup angkatan 2019/2020. Pengumpulan data dilakukan dengan observasi dan wawacara mendalam dan setelah itu dilakukan analisis dengan menggunakan pendekatan Miles dkk yaitu reduksi data, penyajian data dan penarikan kesimpulan. Penelitian ini menemukan simpulan bahwa: Proses penanaman nilai-nilai pendidikan Islam yang dilakukan di UKM Kerohanian dengan mentoring yaitu berawal dari tahapan pembukaan, kegiatan inti, penutup dan evaluasi. Nilai-nilai pendidikan Islam yang ditanamkan ialah akidah, ibadah dan akhlak yang diwujudkan dari berbagai kegiatan atau program yang ada di UKM Kerohanian, Seperti Silaturahim, ifthor jama'i, rihlah atau tadabbur alam dan kunjungan tokoh.
\end{abstract}

Kata kunci: Nilai Pendidikan Islam; model Mentoring

\begin{abstract}
This study aimed to find the answers about inculcating Islamic education values through a mentoring model in the student activity unit (SAU) of spirituality. This study applied a qualitative approach with key informants referring to the student members of the spirituality SAU at IAIN Curup in the academic year of 2019/2020. Data collection was carried out by observation and in-depth interviews, and the analysis was further carried out using the Miles' et al. approach composed of data reduction, data presentation, and conclusion drawing. This study drew a conclusion that: The process of inculcating Islamic educational values carried out in the spirituality SAU by means of mentoring started from the opening, core activities, closing, and evaluation stages. The values of Islamic education instilled extended to faith, worship, and morals realized from various activities or programs existing in the spirituality SAU, such as Silaturahim, ifthor jama'i, rihlah or tadabbur of nature and visitation of figures.
\end{abstract}

Keywords: Islamic education values; mentoring model 


\section{A. PENDAHULUAN}

Pendidikan mempunyai peran penting karena berhubungan erat dengan proses tatanan kehidupan manusia. Pendidikan dapat dikatakan sebagai pelestari sebuah tata nilai dan juga pelestari tata sosial sekaligus sebagai agen perubahan (Warsah, 2018b, 2020). Pendidikan diartikan sebagai suatu upaya dalam mengambangkan pengetahuan setiap jiwa individu dari segala aspek (Warsah \& Nashori, 2021). Dengan adanya pendidikan tentunya akan membantu aktivitas manusia dalam melestarikan dan mengembangkan ilmu pengetahuan agar tetap lestari dengan cara melalui proses penanaman nilai-nilai penddikan Islam (Warsah et al., 2021).

Nilai-Nilai pendidikan Islam sesudah seharusnya ditanamkan serta dibentuk untuk saat ini, bahkan jika terlewatkan maka seharusnya saat ini lebih diperhatikan kembali. Pendidikan Islam merupakan kebutuhan mutlak yang harus dipenuhi bagi kehidupan manusia. Pendidikan dalam Islam, yaitu proses dan praktik penyelenggaran pendidikan yang berlangsung dan berkembang dalam sejarah umat Islam. Karena pendidikan Islam inilah yang akan membentuk individu menjadi pribadi yang berjiwa Islami dengan mengedepankan nilai-nilai pendidikan Islam (Angdreani et al., 2020; Fadilah et al., 2020; Hakim et al., 2020; Ridwan et al., 2020). Untuk menanamkan nilai-nilai pendidikan Islam ini justru, tidaklah mudah bagi seorang guru/pendidik karenanya merupakan tantangan besar untuk pendidik agar dapat nanti menanamkan nilai-nilai Islam kepada peserta didiknya, terlebih juga dibutuhkannya ide keratif, inovatif, serta menarik untuk diterapkan kepada peserta didik (Warsah \& Nuzuar, 2018).

Salah satu solusi atau altenatif untuk menanamkan Nilai-nilai pendidikan Islam saat ini adalah dengan menggunakan model mentoring. Model mentoring ini di desain untuk membentuk pribadi muslim yang integral dan syumul (Yunarman, 2017). Walaupun pada kenyataannya setiap model pembelajaran mempunyai kelebihan dan kurangan tersendiri, namun model mentoring ini mampu menyentuh segala aspek, baik fikriyah, jasadiyah, terlebih lagi pada aspek ruhiyah. Tentunya, model mentoring ini bukanlah satu-satunya model pendidikan yang ditawarkan. Justru, masih banyak lagi model pendidikan dan pembelajaran yang lain yang mampu digunakan untuk menanamkan nilai-nilai pendidikan Islam.

Sebuah hasil penelitian menunjukkan bahwa keberadaan mentoring PAI di Sekolah Tinggi masih sangat positif bagi kalangan mahasiswa, seperti di STIA Banten model mentoring yang dilaksanakan telah mengalami sebuah perubahan baik secara teknis dalam hal pengelolaan. Dimana semula dikelola oleh bidang akademik kemudian dialihkan dan dikelola oleh Lembaga Dakwah Kampus (LDK). Mahasiswa mengalami perubahan dari segi sikap seperti lebih sopan santun dan mempunyai kelebihan pada aspek akademik terutama pada pelajaran Pendidikan Agama Islam (Lutfi, 2016). Dari penelitian tersebut, maka dapat ditarik sebuah kesimpulan bahwa dengan adanya model mentoring ini akan melahirkan nilai-nilai perubahan yang lebih baik terutama dari aspek kerohanian Islam.

Mahasiswa yang masuk dalam kampus IAIN Curup berasal dari latar belakang yang beragam, mulai dari satuan tingkat pendidikan Sekolah Menengah Atas (SMA), Sekolah Menengah Kejuruan (SMK) dimana sangat minim dalam hal agama terutama dalam hal pengetahuan akidah, ibadah dan juga akhlak. Lain halnya dengan mahasiswa yang berasal dari pesantren, Madrasah Aliyyah dan satuan pendidikan yang sejenis mereka dibekali ilmu-ilmu agama dari awal oleh gurunya sejak mereka menempuh pendidikan di institusi pendidikan berwawasan agama tersebut. 
Dalam hal ini, tentunya Mahasiswa IAIN Curup yang menjalankan aktivitas ini, karena Mahasiswa IAIN Curup sendiri dikatakan sebagai Agen Of Change, dimana dituntut agar mengikuti perkembangan zaman dan selalu up to date terhadap berbagai informasi yang sesuai studi masing-masing mahasiswa (Komalasari \& Naumi, 2018; Nugroho et al., 2020). Oleh sebab itu, selain mata kuliah wajib yang ada ditawarkan oleh kampus sebagai pendidikan utama untuk para mahasiswa dalam menggali ilmu dan mendapatkan pengetahuan keislaman di IAIN Curup ada Unit Kegiatan Mahasiswa (UKM) Kerohanian sebagai organisasi internal yang berperan sebagai wadah ataupun tempat mahasiswa mendapatkan wawasan tambahan ataupun sebagai tempat pembinaan yang selama ini bahkan belum diperoleh dari ruang kelas. Tujuan adanya UKM Kerohanian ini ialah sebagai tempatnya mahasiswa untuk memaksimalkan penguasaan materi mahasiswa dalam hal keagamaan, membantu perubahan akhlak dan moral mahasiswa, serta dapat membantu mahasiswa dapat beprestasi dalam segala hal. Sesuai dengan misi UKM Kerohanian sendiri ialah untuk bertakwa kepada Tuhan Yang Maha Esa. Sehingga UKM Kerohanian dipandang perlu untuk menanamkan nilai-nilai pendiidkan Islam untuk kalangan mahasiswa IAIN Curup Khususnya.

UKM Kerohanian memiliki model mentoring yang digunakan sebagai wadah pembinaan untuk para mahasiswa dalam memperoleh sekaligus memperluas wawasan keIslaman. Model mentoring ini memiliki kelebihan yaitu sebagai pembinaan kader, sebagai wadah untuk memperoleh wawasan keilmuan keIslaman pendidikan Islam baik tentang ketuhanan, ibadah keseharian serta tentang hubungan muamalah.

Berdasarkan hasil wawancara yang dilakukan pada tanggal 12 Juni 2020 kepada Jimmi Arianto selaku ketua Unit Kegiatan Mahasiswa (UKM) Kerohanian Cahaya Islam IAIN Curup, beliau menyampaikan bahwa, Pertama. Model pembinaan yang digunakan di UKM Kerohanian yaitu Mentoring. Model mentoring merupakan kegiatan pertemuan pekanan yang terdiri dari beberapa orang yang duduknya melingkar. Model mentoring ini dilaksanakan oleh dua jenis pelaksana yaitu ada yang disebut dengan murrabi (pendidik) dan mutarabbi/mentee (peserta). Kegiatan ini dilakukan di masjid kampus IAIN Curup, bahkan terkadang dilakukan di tamantaman sekitar kampus IAIN Curup. Kedua, Struktur UKM Kerohanian mulai terorganisir semenjak tahun 2019 hingga saat ini. Ketiga, dengan program mentoring banyak sekali ilmu keagamaan yang didapatkan (Wawancara, 25 Juli 2020).

Berdasarkan Observasi yang dilakukan di UKM Kerohanian IAIN Curup bahwa model mentoring yang digunakan saat ialah berbentuk model kelompok dan model virtual. Model kelompok digunakan karena seorang mentor membina peserta mentoring hingga 13 orang dimana mentor memliki peran dan andil yang sangat penting dalam proses pelaksanaan mentoring. Mentoring kelompok biasanya dilaksanakan di masjid Kampus dengan berbagai komponen yang ada seperti murabbi dan mutarabbi, metode, materi, manajemen organisasi dan lain-lain. Kemudian model mentoring virtual digunakan sesuai dengan kondisi saat ini dimana tidak boleh berinteraksi dan berkerumuman, sehingga harus melalui media online sehingga mentoring dilaksanakan melalui media sosial/online (Observasi di UKM Kerohanian, 27 Juli 2020).

Dalam melaksanakan program mentoring ini, Kegiatan Mentoring dilaksanakan sesuai dengan situasi dan kondisi yang ada di UKM Kerohanian, kemudian disesuaikan dengan kreativitas dan inovasi dari masing-masing mentor yang memegang binaan/mentee. Hal ini 
dilakukan agar mentoring dapat dilaksanakan secara kontinyu tanpa harus membebani setiap elemen yang terlibat di dalamnya.

Model Mentoring yang digunakan di UKM Kerohanian terwujud dari berbagai kegiatan yang ada dalam mentoring tersebut, memberikan pengetahuan dan wawasan baru, kemudian wujud kegiatan lainnya seperti Ifthor Jama'i, Rihlah juga sebagai salah satu cara untuk menanamkan nilai-nilai pendidikan Islam. Dari kegiatan tersebut mahasiswa akan menjadi lebih asyik dan senang mengikuti mentoring. Kemudian pelaksanaan kegiatan itu menunjukkan adanya penanaman nilai-nilai pendidikan Islam yang ditanamkan bukan hanya pendidikan Akidah, Ibadah saja melainkan pendidikan muamalah atau akhlak, karena dengan kegiatan tersebut para kader banyak sekali berkumpul bersilaturahim untuk menjaga ukhuwah kebersamaan diantara mereka.

Salah satu konsekuensi jika model mentoring ini tidak lagi digunakan atau tidak lagi berjalan dengan berpijak pada orientasi masa depan, maka masa depan mentoring akan suram. Semua ini disebabkan karena tidak lagi ada yang mampu menghasilkan kader Islami dengan segala sistem transfer ilmu dari segi pendidikan Islam (Ramadhani, 2021). Model mentoring ini sekaligus menjadi jawaban atas beberapa permasalahan kurangnya nilai-nilai pendidikan Islam serta tantangan masa depan dikalangan masyarakat saat ini. Salah satunya ialah yang terlihat dalam jiwa karakter atau jati diri kaula muda. Berdasarkan latar belakang tersebut, maka penelitian ini berupaya mengetahui lebih mendalam tentang Nilai-nilai pendidikan Islam yang ditanamkan melalui model Mentoring di UKM Kerohanian IAIN Curup ini baik tentang proses penanaman nilai tersebut maupun factor pendukung dan penghambatnya.

\section{B. METODE PENELITIAN}

Penelitian ini menggunakan jenis penelitian kualitatif yang sifatnya penelitian lapangan (field research). Sebagaimana menurut Sugiyono bahwa metode penelitian kualitatif ialah metode yang berlandaskan pada filsafat postpositivisme, dimana dipergunakan oleh peneliti pada objek yang alamiah yang mana peneliti sendiri yang menjadi instrumen kuncinya. Teknik pengumpulan data dilakukan dengan triangulasi (gabungan), analisis datanya bersifat induktif atau deduktif, serta hasil penelitiannya lebih menekankan pada aspek makna dari pada generalisasi. Pendekatan yang digunakan dalam penelitian ini ialah deskriftif kualitatif (Sugiyono, 2013).

Menurut Amirin, subjek penelitian berarti sebagai seseorang atau sesuatu yang mengenainya ingin diperoleh keterangan atau orang pada latar penelitian yang dimanfaatkan untuk memperoleh informasi tentang situasi dan kondisi latar dilapangan. Istilah lain tentang menyebut subjek penelitian adalah responden, yaitu oarng yang memberi respon atau suatu perlakuan yang diberikan kepadanya (Fitrah, 2018). Informan ialah orang yang memberikan informasi (Anshori \& Iswati, 2017; Moleong, 2007; Rosyada, 2020). Jadi, Informan dalam penelitian ini adalah ketua UKM Kerohanian, mentor, pengurus UKM Kerohanian dan peserta mentoring di UKM Kerohanian IAIN Curup tahun 2019/2020 .

Sumber Data dalam penelitian ini ada 2 yaitu, primer Dan sekunder. Data primer Data yang di maksud dalam penelitian ini yaitu, Ketua UKM Kerohanian, Pengurus UKM Kerohanian, Mentor, dan Peserta. Sedangkan data sekunder dalam penelitian ini yaitu buku paduan Halaqoh, Daftar nama-nama mentor, Bentuk Silabus, serta berbagai buku dan jurnal yang lainnya untuk menunjang dan mendukung penelitian ini. Teknik Pengumpulan data dalam penelitian ini yaitu Observasi Partisipatif, Wawancara Semi Terstruktur dan Dokumentasi (Ciesielska et al., 2018). 
Kemudian teknik analisis data analisis data menurut Miles dkk yang terdiri dari pengumpulan data, display data, reduksi data dan verifikasi atau kesimpulan (Huberman \& Miles, 2002).

\section{HASIL DAN PEMBAHASAN}

\section{Hasil Penelitian}

Temuan penelitian yang didapatkan dari lapangan tujuannya untuk menjawab pertanyaan penelitian yang telah dirumuskan pendahuluan adalah:

\section{a. Proses penanaman Nilai-nilai pendidikan Islam melalui model Mentoring di Unit Kegiatan Mahasiswa (UKM) Kerohanian Cahaya Islam IAIN Curup.}

Agar dapat mengetahui proses atau pelaksanaan Penanaman Nilai-Nilai Pendidikan Islam melalui Model Mentoring di UKM Kerohanian, Maka peneliti melakukan wawancara dengan Ketua UKM Kerohanian IAIN Curup, hal ini dilakukan karena Ketua Umum UKM Kerohanian memiliki peran yang sangat penting terhadap proses penananaman nilai-nilai pendidikan Islam sekaligus sebagai pengawas dan pengevaluasi semua aktivitas yang telah dilaksanakan oleh seluruh pengurus dan anggota.

Berdasarkan hasil wawancara dengan ketua UKM Kerohanian diatas bahwa mentoring merupakan sebuah model pengajian yang dapat menanamkan nilai-nilai pendidikan Islam seperti pendidikan Akidah, Ibadah dan akhlak. Peneliti ingin memastikan kebenaran tentang Penanaman Nilai-Nilai Pendidikan Islam di UKM Kerohanian, sehingga melanjutkan wawancara yang dilakukan kepada Ketua UKM Kerohanian yaitu Jimmy Arianto:

Jimmi Arianto Menurutnya, bahwa mentoring sebagai sebuah Pembinaan dalam kelompok untuk memberi ilmu kepada peserta. Tujuannya Sebagai pelatihan dan pembekalan ilmu. Manfaatnya supaya ada skill tentang publik speaking dan ilmu keagamaan. Pematerinya ialah mereka yang sudah dilatih dalam pembinaan UKM Kerohanian minimal 2 tahun. Pesertanya terkhusus untuk kader UKM Kerohanian atau umum juga boleh. Salah satu materi yang disampaikan ialah dibidang kepemimpinan, Rasulullah atau Khulafaurrasyidin. Pelaksanannya dikumpulkan peserta dan disampaikan perihal agama. Urutannya ada moderator, tilawah, tadabbur ayat, memahamai isi ayat dan penyampaian oleh murabbi/mentor (Wawancara, 13 November 2020).

Berdasarkan wawancara kepada ketua UKM Kerohanian tersebuat menunjukkan adanya indikasi bahwa di UKM Kerohanian benar adanya proses penanaman nilai-nilai pendidikan Islam terlihat dari materi yang disampaikan dan adanya urutan dalam pelaksanaan model mentoring di UKM Kerohanian.

Sehubungan dengan itu, Penelitian ini akan menjelaskan lebih jauh terkait dengan tahapan mentoring serta proses pelaksanaan Penanaman Nilai-Nilai Pendidikan Islam di UKM Kerohanian tersebut, sehingga melakukan wawancara lagi kepada pengurus UKM Kerohanian dimana mereka selaku pengurus UKM Kerohanian menjelaskan tentang tahapan-tahapan dalam pelaksanaan model mentoring baik kelompok maupun virtual termasuk Model Mentoring mulai dari perencanaan, pelaksanaan, dan evaluasi. Maka wawancara dilakukan kepada Oktia Anisa Putri Selaku Devisi Kaderisasi. Beliau mengatakan bahwa:

"Dalam proses pelaksanaan mentoring, maka setiap mentor memiliki jadwal pertemuan, silabus perencanaan pembelajaran serta modul atau buku paduan yang digunakan untuk 
proses pelaksanaan mentoring yang menjadi pegangannya untuk melaksanakan model mentoring, selain itu ada pelatihan juga bagi seorang mentor guna membekalinya agar mampu melaksanakan model mentoring dengan baik. Ada persyaratan khusus bagi peserta mentoring untuk mengikuti mentoring ini, yang terpenting ialah adanya niat yang kuat untuk melaksanakannya. Sedangkan seorang mentor harus memiliki kemampuan dan kesanggupan dalam melaksanakan mentoring. Dengan adanya model mentoring ini Karena model mentoring sangat cocok dan mudah untuk dilakukan dalam ruang lingkup kampus, selain itu model ini menjadi salah satu model yang dilaksanakan atau dicontohkan oleh Rasulullah dalam dakwahnya. Menurut saya pendekatan dalam model ini sangat efektif untuk membentuk generasi Rabbani” (Wawancara, 6 Desember 2020).

Kemudian untuk mendapatkan penjelasan yang lebih valid maka peneliti melanjutkan melakukan wawancara kepada pengurus UKM Kerohanian yang bertugas pada tahun 2019 yaitu kepada Ayu Sumiati :

"Proses pelaksanaan mentoring dilaksanakan sesuai dengan aturan dalam pelaksanaan didalam UKM Kerohanian. Peserta mentoring harus menjadi anggota, memiliki komitmen yang tinggi untuk memperlajari ilmu Agama. Melalui mentoring inilah tujuan dari UKM Kerohanian akan tercapai yakni mendakwahkan syiar Islam kepada setiap orang terutama mahasiswa. Mentoring biasanya sebelum dilaksanakan maka dilakukan proses pembagian kelompok dengan berdasarkan mentor masing-masing dengan binaannya" (Wawancara, 13 November 2020).

Jadi, dari pendapat diatas dapat disimpulkan bahwa dalam proses pelaksanaan yang dilakukan dengan mentoring maka dilakukan oleh seorang mentor yang mana sejak awal telah diarahkan dan dibina oleh Ketua UKM Kerohanian dan juga pengurus untuk membantu bagaimana cara memberikan materi dan menanamkan nilai-nilai pendidikan Islam kepada peserta. Kemudian Peneliti ingin mengetahui bagaimana proses penanaman nilai-nilai pendidikan Islam melalui model mentoring sehingga melakukan wawancara dengan para mentor UKM Kerohanian.

Seperti yang peneliti lihat pada saat observasi, bahwa benar adanya proses pelaksanaan mentoring di UKM Kerohanian, mentoring biasanya sebagai wadah untuk berbagi pengetahuan dan pengalaman yang biasanya dilaksanakan didalam masjid dengan waktu seminggu sekali dan durasi lebih kurang 2 jam.

Sama halnya dengan perkataan Ririn Eka Monica mengenai proses mentoring yang dilakukan setelah pembukaan, selaku mentor beliau menuturkan tahapan sebagai berikut:

1) Tujuan dan manfaat dari pelaksanaan model mentoring yaitu dapat memberikan pemahaman kepada mutarobbi (mentee) dan memberikan pengarahan yang sesuai dengan ajaran agama Islam.

2) Perencanaan di dalam mentoring selain dari materi yang bisa disampaikan agar kiranya mutarobbi (mentee) tidak merasakan jenuh pada setiap mentoring maka di dalam mentoring terdapat beberapa kegiatan selain dari materi tadi yaitu kita buat adanya perbaruan yaitu ada praktik, games dan juga kuis. Selain kegiatan yang lain adanya kegiatan rihlah, kemudian masak-masak bersama dan makan bersama agar kiranya saling mempererat ukhuwah satu sama lainnya.

3) Kalau secara pribadi untuk memulai pelaksanaan mentoring yaitu perlu adanya persiapkan materi yang mau disampaikan sesuai dengan pemahaman mereka kemudian saya 
memberikan strategi agar kiranya materi yang disampaikan ini bukan hanya materi saja melainkan harus ada contoh baik berupa alat maupun games yang sesuai agar mereka mampu mengimplementasikan materi tersebut.

4) Waktu pelaksanaan pada saat setiap jadwal mentoring diterapkan dengan alokasi waktu kurang lebih dua jam. Dilaksanakan masjid kampus dan biasanya juga di sekitaran lingkungan kampus. Materi yang disampaikan yaitu tentang hubungan manusia dengan Allah, Rasulullah, tentang akhlak dan ibadah Yaumiyah.

5) Metode yang digunakan saat mentoring ialah ceramah, karena adanya tujuan penyampaian yang bersifat searah dan langsung disampaikan dengan langsung. Serta berbagai metode yang dapat digunakan baik indoor maupun yang bersifat outdoor.

6) Bahan ajar yang sering digunakan ialah silabus materi setiap minggunya, buku mentoring pendukung. Serta sarana prasarana yang digunakan yaitu laptop, buku ajar, daftar prensi, buku penunjang, hadist tarbawi.

7) Peserta dalam mentoring yaitu seluruh kader yang aktif di UKM Kerohanian. Mentor memberikan evaluasi dengan peserta mentoring yaitu dengan cara memberikan penugasan kepada mentee dan juga bisa mempertanyakan kepada mereka melalui sharing-sharing secara bergantian kemudian baru terakhir mentor mengevaluasi apa yang didapat selama pelaksanaan model mentoring.

8) Prosedur pelaksanaan mengtoring adalah Pertama yaitu adanya tahap persiapan untuk membangun kegiatan mentoring sehingga dapat mencapai hubungan baik antara mentor dengan mutarobbi (mentee) nya, kemudian agar kiranya menjalin komunikasi antara mentor dengan adek-adek binaan nya perlu adanya komunikasi yang baik seperti halnya berdiskusi sehingga tahap model mentoring ini dapat berjalan dengan baik. Kemudian dari pelaksanaannya yaitu pertama pembukaan, dimana peserta membuka acaranya, kemudian diarahkan untuk infaq majlis, dengan harapan bahwa nantinya berapapun yang diberikan dan diinfaqkan maka akan menjadi wadah dan ladang amal untuk semua peserta mentoring (Wawancara, 17 November 2020)

Setelah melakukan wawancara dengan para mentor yang berasal dari prodi PAI diatas, maka peneliti melakukan wawancara lagi untuk melihat kebenaran apakah yang disampaikan para mentor diatas memiliki kesamaan prosedur ataukah tidak. Sehingga peneliti melakukan wawancara kepada Nurul Hasanah selaku mentor juga sekaligus Sekretaris Jendral dari UKM Kerohanian tentang proses kegiatan inti dalam pelaksanaan mentoring, beliau mengungkapkan bahwa:

Waktu pelaksanaan mentoring yaitu 1 hingga dua jam, bertempat di masjid dan tempat menarik lainnya, materinya seputra pendidikan karakter dan saling menghargai juga sesuai buku paduan, metode yang digunakan yaitu diskusi, tanya jawab dan quis. Pesertanya ialah kader UKM Kerohanian. Cara mentor untuk mengevaluasi peserta ialah melihat keseharian serta wajibat dari masing-masing peserta. Prosedur pelaksanaannya ialah pembukaan, tilawah, tadabbur ayat, penyampaian materi dari mentor, Kabar baik dan buru dan penutup. dalam kegiatan inti pelaksanaan mentoring pengurus mengarahkan untuk para mentor menyampaikan materi sesuai silabus atau buku paduan, kemudian membawa referensi tambahan untuk mendukung penyampaian materi, setelah proses itu selesai maka hal yang dilakukan ialah ta'limat atau pengumuman, dimana para peserta diberikan arahan dan 
berbagai macam masukan terkait dengan informasi yang membantu perkembangan dakwah di UKM Kerohanian khususnya agenda mentoring ini serta penyampaian kabar baik dan buruk dari pengalaman dan aktivitas para mentee di hari sebelumnya (Wawancara, 17 Oktober 2020).

Jadi, berdasarkan hasil wawancara dengan para mentor dijelaskan bahwa adanya proses penanaman nilai-nilai pendidikan Islam yang dilakukan, para mentor memiliki cara yang khusus untuk memberikan materi keIslaman kepada para peserta dengan paduan buku yang sudah disiapkan oleh pengurus. Proses atau laangkah-langkah dari mentoring itu sendiri sudah dijelaskan oleh masing-masing mentor dengan gaya penyampaian dan ciri khas mereka masing-masing.

Berdasarkan uraian di atas, maka perlu dipastikan kebenaran dari pendapat dan jawaban dari para mentor terkait dengan proses pelaksanaan dalam kegiatan ini maka peneliti melakukan wawancara dengan peserta mentoring:

Dosi Cahaya menurutnya, bahwa dalam kegiatan ini diberikan tausiah dan ceramah dari murabbiyah dengan berbagai macam materi keIslaman, kemudian membicarakan rencana kegiatan apa yang ingin dilaksanakan untuk kemudian hari agar peserta tidak mudah jenuh dan bosan (Wawancara, 25 September 2020). Muhammad Feby Parnanda menurutnya, setelah pengumuman biasanya diberikan penyampaian kabar baik dan buruk, sekaligus tanya jawab dimana kami bercerita tentang masalah kemudian murabbi menelaah dan menganalisa pemecahan masalahnya. Dengan berbagai problem solving ini maka semua peserta menjadi lebih dihargai dan dibantu untuk menyelesaikan masalah-masalah yang sedang dihadapi (Wawancara, 13 November 2020)

Kemudian peneliti melakukan wawancara lagi dengan peserta mentoring dari mahasiswa PAI tentang kegiatan penutup dan evaluasi dari agenda mentoring, Reki Tri Andriani beliau mengatakan bahwa: "Setelah melaksanakan mentoring dari kegiatan inti yang kami ikuti, selanjutnya kami diarahkan dengan evaluasi dimana ditanya tentang ibadah keseharian mulai dari solat wajib, sunnah, puasa sunnah, dhuha dan lain-lain dengan buku mutabaah mentor. Kemudian sekaligus penutup agenda, pada tahap ini kami diberikan kesimpulan akhir dari apa yang dibahas oleh mentor mengenai tema hari itu. Setelah itu, maka dilaksanakan kegiatan penutup (Wawancara, 13 Oktober 2020).

Sementara dijelaskan juga oleh Azizul Akbar selaku mahasiswa PAI yang mengikuti mentoring dari semester 3, beliau mengatakan bahwa: "Menurut saya kegiatan mentoring pada tahap akhir yaitu kami diarahkan untuk membaca doa yang dipimpin oleh ketua kelompok serta akhirnya doa kifaratul majlis, sebelumnya kami diberikan kesimpulan dari materi bahasan yang telah didiskusikan oleh mentor kepada peserta" (Wawancara, 12 November 2020).

Selanjutnya wawancara dilakukan kepada Miftahul Jannah selaku mentor tentang proses penanaman nilai-nilai pendidikan Islam yang dilakukan oleh UKM Kerohanian melalui model mentoring, beliau mengemukakan bahwa: "Penanaman nilai-nilai pendidikan Islam dilakukan dengan berbagai hal, seperti menyampaikan materi tentang keIslaman, dimana terdapat materi seperti syahadatain. Kemudian mengingatkan para mentee untuk selalu beribadah baik wajib dan sunnah, kemudian jika bosan maka kami mengajak untuk mereka jalan-jalan atau rihlah ke tempattempat wisata untuk menghilangkan stress" (Wawancara, 18 Oktober 2020).

Berdasarkan hasil wawancara kepada Fridiyanto Cahyono selaku mentor tentang penanaman nilai-nilai pendidikan Ibadah, bahwa beliau mengemukakan bahwa: "Pelaksanaan nilai 
ibadah dilaksanakan dengan cara para mentee selalu diingatkan selalu tentang bahaya meninggalkan ibadah, selalu diberikan motivasi dengan ibadah bahwa akan mendapat pahala dan pertolongan Allah Swt. Nilai ibadah yang diberikan kepada peserta yaitu seperti selalu diingatkan tentang ibadah yaumiyah serta selalu diingatkan tentang memanfaatkan waktu dengan sebaikbaiknya, biasanya ditegaskan dengan adanya taklimat kader" (Wawancara, 18 Oktober 2020).

Selanjutnya wawancara kepada Aji Saputra selaku mentor, tentang penanaman nilai-nilai pendidikan Akhlak kepada mentee, beliau mengemukakan bahwa: "Proses penanaman nilai-nilai pendidikan akhlak dilakukan dengan cara mengajak para peserta untuk selalu bersilaturahim antar kader, baik satu mentoring atau lain mentoring, kemudian melaksanakan kegiatan tadabbur alam rihlah dakwah misalnya kepantai panjang dan tempat bersejarah, kemudian silaturahim dakwah anar kader dan lainnya" (Wawancara, 18 Oktober 2020).

Kemudian dilanjutkan oleh Restu Abdiyantoro selaku mentee, beliau mengemukakan bahwa: "Kegiatan yang sering kami dapati di mentoring yaitu seperti kegiatan tukar kado, rujak party dimana kami tidak hanya diberikan materi pelajaran saja namun kami juga diarahkan dan diberikan tentang motivasi agar bisa semangat dalam mentoring salah satu buktinya kegiatan outdoor ini kami kumpul untuk satu sama lain saling bertukar kado. Kegiatan ini saya rasa sangat penting dan menarik untuk diikuti dikalangan mahasiswa IAIN Curup, selain untuk menambah ukhuwah juga memberikan makna saling berbagi dan saling memahami antar satu sama lainnya, khususnya kader UKM Kerohanian" (Wawancara, 18 Oktober 2020).

Selain model mentoring kelompok diatas, model mentoring virtual juga dilaksanakan oleh UKM Kerohanian saat ini, melihat situasi dan kondisi sehingga harus dilakukan mentoring dengan model virtual. Dari hasil wawancara kepada Ririn Eka Monica selaku mentor, diperoleh bahwa Proses Pelaksanaan Model Mentoring secara Virtual di UKM Kerohanian Sebagai berikut:

Proses pelaksanaan mentoring virtual yang kami terapkan menggunakan aplikasi whatsapp, karena kami melihat situasi saat ini yaitu masih pandemi jadi dilarang untuk berkerumuman atau berkumpul secara banyak. Pelaksanaan mentoring yang kami lakukan yaitu dengan membagikan kader berdasarkan kelompok masing-masing dimana telah disusun oleh pengurus UKM Kerohanian. Kemudian susunan acaranya mulai dari pembukaan dimana dilakukan absensi terhadap peserta mentoring, kemudian dilanjutkan dengan tilawah al-qur'an dan mentadaburrinya, kemudian sesi tanya jawab dan akhirnya doa penutup. secara kontinyu pelaksanaan ini dilakukan oleh kalangan mentor yang ada di UKM Kerohanian IAIN Curup (Wawancara, 18 Oktober 2020).

Selanjutnya peneliti melakukan wawancara dengan Fridiyanto Cahyono mengenai proses pembukaan mentoring. Wawancara ini dilakukan secara daring melalui media whatsapp, beliau mengatakan: "Proses pembukaan yang grup kami lakukan ialah dengan cara menyampaikan kalimat pembuka dengan basmallah terlebih dahulu kemudian dilanjutkan dengan pujian terhadap Allah Swt dan sholawat atas nabi Muhammad Saw. Kemudian pesan-pesan takwa kepada para mentee agar tetap yakin dan kuat keimanannya dalam dakwah ini” (Wawancara, 18 Oktober 2020). Setelah proses pembukaan berupa muqaddimah maka selanjutnya dilakukan absensi per mentee untuk melihat kehadirannya dalam kegiatan mentoring virtual, karena dengan absensi akan dilihat antusias peserta untuk mengikuti mentoring secara online.

Kemudian disampaikan kembali kepada Ririn Eka Monica, bahwa setelah mengetahui kehadiran para mentee berarti telah siap untuk mengikuti arahan dan pelaksanaan mentoring secara 
virtual, maka selanjutnya ialah tilawah Al-Qur'an dilakukan dengan cara mengirimkan voice note di grup mentoring virtual, mentee yang lain mendengarkan melalui android masing-amsing, kemudian menyampaikan berbagai informasi yang akan disampaikan sebagai hal-hal yang up to date kepada para mentee (Wawancara, 18 Oktober 2020).

Selanjutnya salah satu mentee yaitu Azizul Akbar memberi informasi tentang proses penyampaian materi ketika mentoring secara virtual, beliau mengemukakan bahwa: "Penyampaian materi yang dilakukan didalam grup kami yaitu, mentor memberikan materi berupa tulisan melalui whatsapp, materi yang disampaikan bermacam-macam mulai dari tentang ukhuwah, ibadah harian, dan tentang wawasan keIslaman. Materi dishare atau dibagikan oleh mentor kepada kami peseertanya kemudian kami membaca dan menyimak serta juga mempelajari materi yang disampaikan untuk dipahami secara mendalam" (Wawancara, 18 Oktober 2020).

Dilanjutkan pada hasil wawancara kepada Armen Sudomo selaku mentee tentang proses yang dilakukan setelah penyampaian materi selesai disampaikan, beliau menyampaikan bahwa: "Setelah materi kami baca dan simak dari yang disebarkan oleh mentor kami, kami langung diarahkan untuk bertanya tentang hal yang belum kami pahami dan belum kami mengerti, contohnya saja materi yang disampaikan mentor kami yaitu tentang pentinya menjaga ucapan, maka selanjutnya kami langsung melaksanakan prosesi tanya jawab menanyakan mengapa pentingnya menjaga lisan itu. Kemudian mentor menjawab berbagai pertanyaan yang kami ajukan" (Wawancara, 18 Oktober 2020).

Selanjutnya masih berkaitan dengan proses pelaksanaan mentoring, disampaikan oleh Fridiyanto Cahyono selaku mentor bahwa tahap terakhir dalam mentoring virtual setelah prosesi tanya jawab ialah doa penutup, dimana mentee diminta untuk menyampaikan doa baik dalam tulisan maupun voice note secara langsung di aplikasi whatsapp yang digunakan.

Berdasarkan hasil dokumentasi dalam buku paduan mentoring UKM Kerohanian, menjelaskan tentang bagian-bagian dari proses untuk penyampaian materi mentoring yaitu Adanya Tujuan, Metode Pendekatan, Alokasi Waktu, Games; terdiri dari Judul materi, Langkah-langkah, dan Hikmah, Rincian bahasan, dan Referensi.

\section{b. Faktor Pendukung dan Penghambat penerapan Model Mentoring dalam penanaman Nilai-nilai Pendidikan Islam UKM Kerohanian IAIN Curup}

1) Faktor mendukung

Berdasarkan wawancara dengan Mentor, Miftahul Jannah beliau mengemukakan bahwa: "Dalam melaksanakan mentoring faktor-faktor yang mendukungnya ialah tempat yang strategis, kesiapan mentee dalam mengikuti mentoring dan kesiapan mentor baik secara fisik maupun non fisik" (Wawancara, 18 Oktober 2020).

Kemudian peneliti melakukan wawancara dengan Ririn Eka Moinica selaku mentor, ia mengemukakan bahwa: "Faktor yang menjadi pendorong dalam pelaksanaan mentoring ialah buku penunjang yang telah disusun, adanya peserta mentoring, dan adanya alat untuk mensukseskan mentoring itu sendiri. Materi yang teklah tersusun dengan sistematis sehingga hanya membutuhkan kreativitas dan inovasi mentor saja harapannya para mentee akan tertarik dan merasa tidak jenuh atau bosan" (Wawancara, 17 November 2020).

Kemudian peneliti melakukan wawancara kembali dengan Ketua UKM Kerohanian, dimana beliau sebagai tempat para mentor memberikan evaluasi terkait dengan mentoring itu 
sendiri, beliau mengemukakan bahwa: "Faktor pendukung dalam pelaksanaan mentoring bagi mentor dan peserta itu sendiri ialah adanya semangat dari mentee atau peserta, adanya kemauan yang tidak puas dengan ilmu, dan adanya ukhuwah yang erat. Adanya kegiatan yang menarik yang mendukung kegiatan dalam mentoring karena sebelumnya telah diarahkan oleh pengurus. Kemudian adanya antusiasme para pesera dan mentor sehingag menumbuhkan suasana enak dan nyaman selama mentoring (Wawancara, 13 November 2020).

Berdasarkan informasi dari narasumber tergambar bahwa faktor pendorong yang dapat membantu kesukseskan dalam penanaman nilai-nilai pendidikan Islam dapat berasal dari internal yaitu diri peserta itu sendiri dan eksternal yaitu berasal dari luar diri peserta dan mentor seperti tempat yang strategis. Sejalan dengan data observasi yang dilakukan, terlihat secara jelas bahwa sebelum melaksanakan mentoring seorang mentor dibekali pengetahuan oleh pengurus, buku penunjang atau pedoman khususyang terkait dengan materi serta pembekalan materi yang diberikan agar nantinya para mentor tidak lagi kaget bahkan tidak mengetahui apa saja bahan yang akan disampaikan ketika pelaksanaan mentoring. Dengan demikian target yang akan dikerjakan dan dicapai oleh UKM kerohanian melalui mentoring ini akan tercapai yakni menanamkan nilainilai pendidikan Islam (Observasi di UKM Kerohanian, 10 September 2020).

Hasil observasi yang dilakukan oleh peneliti dengan melihat digrup whats'app para mentor, bahwa setiap minggunya para mentor selalu mengisi daftar hadir karena telah melaksanakan mentoring baik tatap muka maupun via daring atau media sosial. Artinya menunjukkan bahwa salah satu faktor yang mendukung kesuksekan mentoring ini ialah adanya media sosial yang mana akan mendukung kelancaran dakwah UKM Kerohanian (Observasi di UKM Kerohanian, 10 September 2020).

Hasil dokumentasi yang peneliti lihat berdasarkan absensi kehadiran dari mentor, terlihat bahwa sebagian besar peserta selalu antusias dalam mengikuti mentoring, hal ini mengindikasikan bahwa pelaksanaan mentoring tentu akan berjalan dengan sangat baik jika adanya komunikasi yang baik antara mentor dan menteen (Dokumentasi, Absensi Kehadiran Mentor).

\section{2) Faktor Penghambat}

Faktor yang menghambat proses penanaman nilai-nilai pendidikan Islam melalui model mentoring di UKM Kerohanian antara lain: Menurut Miftahul Jannah, selaku mentor UKM Kerohanian ia mengemukakan bahwa: "Faktor yang menghambat proses pelaksanaan mentoring ialah waktu yang terkadang bertabrakan dengan jadwal yang lain sehingga tertunda dan futur yaitu rasa malas yang mendatangi diri sehingga malas dalam mengikuti mentoring" (Wawancara, 18 Oktober 2020).

Jimmy Arianto, selaku ketua UKM Kerohanian mengemukakan hal yang senada pula bahwa: "Mentoring sering menjadi hal yang membosankan ketika timbul rasa kejenuhan dalam diri peserta bahkan mentor itu sendiri, kemudian tidak adanya isu-isu aktual tentang Islam yang disampaikan oleh mentor. Para mentee masih sering melanggar taklimat kader, karena biasanya dijelaskan dan diarahkan di grup kelompok sebagai pengecasnya. Akan tetapi karena fitur dan goyah keinginannya menjadi terlanggar" (Wawancara, 13 November 2020).

Pertanyaan-pertanyaan penting lainnya juga ditanyakan kepada narasumber adalah: Menurut Ririn Eka Monica, selaku mentor juga dalam pelaksanaan mentoring "mentoring akan terhambat jika para peserta yang mengikuti (mentee) tidak aktif berpastisipasi dalam mentoring. Kalau mentoring online biasanya karena rumah yang jauh menajdikan terkendala dalam jaringan 
apablagi jika situasi hujan membuat kewalahan untuk bekomunikasi via android" (Wawancara, 17 November 2020).

Azizul Akbar selaku Peserta/mentee, mengatakan bahwa: "Selaku peserta kami terkadang merasakan beberapa penghambat yang akan biasanya membuat bosan dan jenuh bahkan ngantuk salah satunya ialah kurangnya inovasi mentor dalam menyampaikan pembinaan kepada kami mentee, juga bahkan terkadang situasi yang membuat jenuh dan bosan (Wawancara, 12 November 2020).

Berdasarkan hasil observasi di UKM Kerohanian, bahwasannya faktor-faktor penghambat penanaman nilai-nilai pendidikan Islam yaitu berasal dari diri peserta itu sendiri dan juga berasal dari faktor luar, seperti waktu yang terkadang belum bisa memanajemen dengan baik, rasa malas yang datang, kemudian lokasi rumah yang jauh, biaya untuk datang ke kampus terkadang terhambat, biaya untuk membeli kuota tidak ada, jaringan yang buruk dan lain sebagainya (Observasi di UKM Kerohanian, 10 September 2020).

Paparan data di atas memberikan gambaran bahwa, faktor penghambat mentor dalam menanamkan nilai-nilai pendidikan Islam yaitu dapat berasal dari dalam peserta atau mentor, seperti rasa jenuh, bosan, malas dan furur. Bahkan juga juga dapat berasal dari luar peserta atau mentornya, seperti cuaca yang tidak mendukung, waktu yang tidak sesuai dengan kondisi masingmasing peserta mentoring.

\section{Pembahasan}

Menurut Satria Hadi Lubis dalam bukunya Menggairahkan perjalanan halaqah, bahwa mentoring ialah istilah yang erat hubungannya dengan pendidikan, khususnya pendidikan Islam (tarbiyah Islamiyah) (Lubis, 2006). Mentoring adalah sekumpulan orang yang ingin mempelajari dan mengamalkan Islam secara serius berkisar antara 3-13 orang dengan mengkaji sebuah kurikulum (manhaj) tertentu. Mentoring mempunyai persamaan dengan halaqoh, ta'lim, pengajian kelompok, tarbiyah atau sebutan lainnya.

Definisi selanjutnya terkait mentoring adalah sebagaimana dijelaskan oleh Muhammad Sajirun dalam buku Manajemen Halaqoh Efektif, bahwa mentoring atau halaqah berasal dari bahasa Arab yakni halqah artinya kumpulan orang-orang duduk melingkar. Dengan kata lain, bahwa mentoring ini adalah proses pembelajaran di mana muridnya melingkari gurunya. Tujuannya agar informasi yang disampaikan anntinya akan menyentuh ranah pengetahuan, sikap serta perbuatan. Dengan kata lain juga termasuk aspek ilmu, akhlak dan amal (Sajirun, 2011).

Berdasarkan data yang didapakan oleh peneliti dilapangan menunjukkan adanya proses atau pelaksanaan mentoring ini sebenarnya dikembalikan dengan cara dan teknik dari masingmasing mentor dengan tetap berpacu dengan gambaran susunan acara yang telah ada sebelumnya. Proses penanaman nilai-nilai pendidikan Islam yang terdiri dari akidah, ibadah dan akhlak direalisasikan/diwujudkan dengan berbagai macam kegiatan dan materi yang disamapaikan seperti ifthor jama'i, rihlah dan lainnya.

Berkaitan dengan teknis lain dalam pelaksanaan mentoring terkait dengan metode serta materi dalam mentoring pada abad ini yaitu dapat dilakukan dengan metode Active learning, Creative learning, E-learning, Cooperative learning (Sajirun, 2011) dan berbagai materi yang dapat disampaikan dapat berkaitan dengan muwashafat seperti akidah yang lurus, ibdaha yang benar dan diterima, serta memiliki akhlak yang baik (Sajirun, 2011). 
Proses atau pelaksanaan dari penanaman nilai-nilai pendidikan Islam melalui model mentoring ini dapat dijelaskan secara umum sebagai berikut:

a. Pembukaan: Kegiatan pendahuluan ini merupakan pelaksanaan mentoring tahap awal pada saat memulai mentoring. Sebelum acara inti mentoring dimulai, maka adanya acara pembukaan biasanya dengan muqaddimah, tilawah serta tadabbur ayat.

b. Kegiatan inti atau isi: Kegiatan inti merupakan pelaksanaan dari mentoring itu sendiri, dimana isinya yaitu penyampaian materi yang disampaikan oleh mentor sekaligus tanya jawab atau diskusi yang dilaksanakan seputar materi mentoring yang dibahas pada saat itu. Dalam kegiatan inti ini, berbagai cara digunakan oleh mentor dalam melaksanakan mentoring, seperti menggunakan metode ceramah, diskusi, metode kisah, metode hapalan dan lain-lain. Selain menggunakan metode, media yang sering digunakan untuk mendukung pelaksanaan mentoring ini seperti media gambar baik yang berasal dari buku, media sosial maupun lainnya, kemudian lingkungan dapat dijadikan media dalam pembelajaran dalam mentoring, bahkan buku, kertas, dan alat tulis lainnya digunakan untuk kegiatan mentoring pada acara inti ini.

c. Penutup: Kegiatan penutup dilakukan dengan adanya refleksi kegiatan biasanya diisi dengan tukar pengalaman, kabar baik dan kabar buruk dari masing-masing peserta. Setelah semua telah dilaksanakan maka sebelum beranjak dari tempat mentoring, maka dilakukan doa penutup.

d. Evaluasi: Evaluasi dari pelaksanaan mentoring ini berupa pengecekan ibadah masingmasing peserta, evaluasi dari keberhasilan program dalam mentoring, evaluasi kehadiran mentoring, dan sebagainya.

Adapun Faktor pendorong secara teoretis yang dapat mempengaruhi proses penanaman nilai-nilai pendidikan Islam melalui mentoring adalah mentor, peserta (mentee), buku penunjang, alat-alat penunjang, tempat atau lingkungan dan teknologi (media sosial), serta adanya ukhuwah. Mentor atau guru menjadi faktor penting dalam mendorong kesuksesan pelaksanaan mentoring. Menurut Al-Gazali, hakekat dari guru ialah orang yang mengajar dan mengajak anak diri untuk taqarrub pada Allah dengan mengajarkan ilmu pengetehuan dan menjelaskannya (Umro, 2020; Warsah, 2018a).

Guru harus mampu untuk membuat suasana menjadi lebih menarik, karena ketika seorang siswa sudah merasakan nyaman dilingkungan sekolah, maka siswa akan seketika itu juga akan terbawa dalam suasana yang dibangun oleh guru, karena guru dituntut untuk memiliki kecakapan serta mampu terhadap apa yang diinginkan oleh para siswa untuk mencapai tujuan yang dinginkan oleh undang-undang SISDIKNAS No 20 Tahun 2003 Bab I pasal 1 yaitu untuk mengembangkan potensi dirinya (Rumondor \& Sineke, 2020; Warsah, 2020; Warsah \& Uyun, 2019).

Selain guru, faktor lain yang memiliki pengaruh besar untuk mendorong keberhsailan model mentoring ini ialah peserta atau murid. Seyogyanya murid memiliki karakter yang berbedabeda (Erdiyanto et al., 2020; Munir \& Latifah, 2020). Peran guru atau mentor dalam hal ini justru harus lebih dominan, karena mengingat karakter yang berbeda-beda yang mereka miliki. Mentoring juga akan berhasil jika didukung oleh faktor lingkungan dan media sosial/internet yang pada zaman ini sangat dibutuhkan bahkan diperlukan untuk menunjang tercapainya program mentoring yang lebih maksimal. 
Penjelasan tersebut memberikan kesimpulan bahwa faktor yang dapat mendorong dalam proses penanaman nilai-nilai pendidikan Islam melalui model mentoring ialah: a) Faktor Internal, yaitu berasal dari diri individu itu sendiri, seperti kesiapan mentor dalam membina peserta, keterlibatan dan keaktifan peserta mentoring, suasana batin dari peserta mentoring, misalnya aktif, semangat dan selalu hadir tanpa absen; b) Faktor Eksternal, yaitu faktor yang beraal dari faktor luar diri individu, seperti buku paduan yang tersedia, tempat yang strategis dan nyaman, kegiatan yang menyenangkan, teknologi yang mendukung seperti jaringan internet yang bagus dan lain sebagainya.

Sementara Faktor penghambat yang dapat mempengaruhi proses penanaman nilai-nilai pendidikan Islam melalui mentoring adalah mentor, peserta, bahkan hal-hal yang berkaitan dengan faktor luar atau lingkungan. Uraian ini menemukan fakta bahwa faktor yang dapat menghambat dalam proses penanaman nilai-nilai pendidikan Islam melalui model mentoring ialah: Faktor Internal, yaitu berasal dari diri individu itu sendiri, seperti timbulnya rasa malas, bosan dan futur; Faktor Eksternal, yaitu faktor luar yang ikut memperngaruhi individu dalam melaksanakan aktivitas, seperti lokasi rumah yang jauh dari tempat mentoring, biaya atau ongkos tidak ada, jadwal atau waktu bertabrakan dengan jam kuliah/belajar, materi yang membosankan, bahkan terkadang terkendala pada jaringan internet.

\section{KESIMPULAN}

Penanaman Nilai-Nilai Pendidikan Islam melalui Model Mentoring di UKM Kerohanian Cahaya Islam IAIN Curup tahun 2019/2020 adalah: Pertama, Proses penanaman nilai-nilai pendidikan Islam yang dilakukan di UKM Kerohanian dengan mentoring yaitu berawal dari tahapan pembukaan, kegiatan inti, penutup dan evaluasi. Nilai-nilai pendidikan Islam yang ditanamkan ialah akidah, ibadah dan akhlak yang diwujudkan dari berbagai kegiatan atau program yang ada di UKM Kerohanian, Seperti Silaturahim, ifthor jama'i, rihlah atau tadabbur alam dan kunjungan tokoh; Kedua, Faktor pendukung dan penghambat dalam menanamkan nilai-nilai pendidikan Islam melalui model mentoring yaitu Faktor pendukung motivasi peserta (mentee) dan mentor, materi yang telah tersusun dengan sistematis, kegiatan yang menarik. Sedangkan, faktor pengahambatnya seperti suasana yang tidak menyenangkan, kebosanan dari mentee, mentee masih sering melanggar taklimat kader, serta pengaruh dari adanya jaringan media sosial yang lambat karena faktor lingkungan khusus pada mentoring virtual.

\section{DAFTAR PUSTAKA}

Angdreani, V., Warsah, I., \& Karolina, A. (2020). Implementasi Metode Pembiasaan: Upaya Penanaman Nilai-Nilai Islami Siswa SDN 08 Rejang Lebong. At-Ta'lim: Media Informasi Pendidikan Islam, 19(1), 1-21. https://doi.org/10.29300/attalim.v19i1.3207

Anshori, M., \& Iswati, S. (2017). Metodologi Penelitian Kuantitatif. Surabaya: Airlangga University Press.

Ciesielska, M., Boström, K. W., \& Öhlander, M. (2018). Observation Methods. In M. Ciesielska \& D. Jemielniak (Eds.), Qualitative Methodologies in Organization Studies: Volume II: Methods and Possibilities (pp. 33-52). Springer International Publishing. https://doi.org/10.1007/978-3-319-65442-3_2 
Erdiyanto, E., Asha, L., Warsah, I., \& Hamengkubuwono, H. (2020). Manajemen Peningkatan Mutu Pendidikan Di Madrasah Aliyah Negeri O2 Lebong, Bengkulu. Islamic Management: Jurnal Manajemen Pendidikan Islam, 3(02), 234-250. https://doi.org/10.30868/im.v3i2.840

Fadilah, F. R., Warsah, I., \& Wanto, D. (2020). Implementasi Outdoor Learning: Upaya Menanamkan Nilai-nilai Keislaman Siswa SDIT Cahaya Rabbani Kepahiang. Edugama: Jurnal Kependidikan Dan Sosial Keagamaan, 6(1), 38-55. https://doi.org/10.32923/edugama.v6i1.1253

Fitrah, M. (2018). Metodologi penelitian: Penelitian kualitatif, tindakan kelas \& studi kasus. CV Jejak (Jejak Publisher).

Hakim, M. L., Sugiatno, S., Yanuarti, E., \& Warsah, I. (2020). Strategi Tokoh Adat Dalam Meningkatkan Pemahaman Agama Islam Anak SAD (Suku Anak Dalam). At-Ta'lim: Media Informasi Pendidikan Islam, 19(1), 145-168. https://doi.org/10.29300/attalim.v19i1.3395

Huberman, M., \& Miles, M. B. (2002). The Q ualitative Researcher's Companion. SAGE.

Komalasari, B., \& Naumi, A. T. (2018). Analisis Penggunaan Internet Sebagai Referensi Mahasiswa Stain Curup (Studi Manfaat dan Dampak Media Massa). Jurnal Dakwah Dan Komunikasi, 3(1), 59-78.

Lubis, S. H. (2006). Rahasia Kesuksesan Halaqoh (Usroh). Tanggerang: FBA Press.

Lutfi, 1. (2016). Model mentoring pai dalam peningkatan sikap dan pemahaman mata kuliah agama islam bagi mahasiswa stia banten. Jurnal NIAGARA, 8(2), 16-24.

Moleong, L. J. (2007). Metode Kualitatif Penelitian. Bandung: PT. Remaja Rosdakarya.

Munir, M., \& Latifah, L. (2020). Kreatifitas Kepemimpinan Guru Dalam Pendidikan Karakter Siswa MA TMI Al-Amien Prenduan. EDUSIANA: Jurnal Manajemen Dan Pendidikan Islam, 7(1), 01-13.

Nugroho, E. W., Warsah, I., \& Amin, M. (2020). Peran Organisasi Ekstra Kampus Dalam Meningkatkan Kemampuan Komunikasi Mahasiswa. Jurnal Dakwah dan Komunikasi, 5(2), 205-224. https://doi.org/10.29240/jdk.v5i2.2156

Ramadhani, Y. (2021). Ideologi Keagamaan, Partai Politik, dan Pendidikan Islam: Refleksi Pemikiran Hasan Al-Banna di Sekolah Islam Terpadu Ukhuwah Banjarmasin. NALAR: Jurnal Peradaban Dan Pemikiran Islam, 5(1), 78-92.

Ridwan, I., Muhibah, S., Maisaroh, I., \& Ngulwiyah, I. (2020). Islamic Education And Civil Society. Jurnal Pendidikan Karakter JAWARA (Jujur, Adil, Wibawa, Amanah, Religius, Akuntabel), 6(2).

Rosyada, D. (2020). Penelitian Kualitatif Untuk Ilmu Pendidikan. Prenada Media.

Rumondor, P., \& Sineke, R. N. (2020). Pola Interaksi Guru PAI Dengan Siswa Dalam Meningkatkan Hasil Belajar Di SMA Negeri 1 Belang. AL-HIKMAH (Jurnal Pendidikan Dan Pendidikan Agama Islam), 2(2), 160-172. 
Sajirun, M. (2011). Manajemen Halaqah Efektif. Solo: Era Adicitra Intermedia.

Sugiyono, S. (2013). Metode penelitian kualitatif. Bandung: Alfabeta.

Umro, J. (2020). Tantangan Guru Pendidikan Agama Islam Dalam Menghadapi Era Society 5.0. Jurnal Al-Makrifat Vol, 5(1).

Warsah, I. (2018a). Interkoneksi Pemikiran Al-Ghazāli dan Sigmund Freud Tentang Potensi Manusia. Kontekstualita, 32(01), Article 01. http://ejournal.lp2m.uinjambi.ac.id/ojp/index.php/Kontekstualita/article/view/30

Warsah, I. (2018b). Pendidikan Keimanan Sebagai Basis Kecerdasan Sosial Peserta Didik: Telaah Psikologi Islami. Psikis: Jurnal Psikologi Islami, 4(1), 1-16. https://doi.org/10.19109/psikis.v4i1.2156

Warsah, I. (2020). Religious Educators: A Psychological Study of Qur'anic Verses Regarding alRahmah. AL QUDS: Jurnal Studi Alquran Dan Hadis, 4(2), 275-298. https://doi.org/10.29240/alquds.v4i2.1762

Warsah, I., Morganna, R., Uyun, M., Hamengkubuwono, \& Afandi, M. (2021). The Impact of Collaborative Learning on Learners' Critical Thinking Skills. International Journal of Instruction, 14(2), 443-460.

Warsah, I., \& Nashori, F. (2021). Model Of Everyone Is A Teacher Here: Solution To Build Up Students' Self-Confidence. Jurnal Psikologi Integratif, 8(2), 1-17. https://doi.org/10.14421/jpsi.v8i2.2061

Warsah, I., \& Nuzuar, N. (2018). Analisis Inovasi Administrasi Guru Dalam Meningkatkan Mutu Pembelajaran (Studi Man Rejang Lebong). EDUKASI: Jurnal Penelitian Pendidikan Agama Dan Keagamaan, 16(3), Article 3. https://doi.org/10.32729/edukasi.v16i3.488

Warsah, I., \& Uyun, M. (2019). Kepribadian Pendidik: Telaah Psikologi Islami. Psikis : Jurnal Psikologi Islami, 5(1), 62-73. https://doi.org/10.19109/Psikis.v5i1.3157

Yunarman, S. (2017). Model Halaqoh sebagai Alternatif Pembentukan Karakter Islami Mahasiswa IAIN Bengkulu. J urnal IImiah Syi' ar, 17(1), 83-94. 